\title{
Response of Yield and Yield Components of Field Pea to Tillage Frequency, Phosphorus Fertilization and Weed Control on Nitisols of Central Ethiopian Highlands
}

\author{
Getachew Agegnehu* and Hailu Beyene
}

Holetta Agricultural Research Center, Ethiopian Institute of Agricultural Research, P O Box 2003, Addis Ababa, Ethiopia

\begin{abstract}
The effects of tillage frequency, phosphorus fertilizer and weed control on yield and yield components of field pea (Pisum sativum L.) were studied in the 2003 and 2004 main cropping seasons on farmers' fields in the Chelia and Welmera Districts of west Shewa, Ethiopia. Four levels of tillage frequency (T4 = April, May, early June and at planting; T3 = May, early June and at planting; T2 = May and at planting and T1 = at planting) as main plots and factorial combinations of four levels of phosphorus fertilizer $\left(0,10,20\right.$ and $\left.30 \mathrm{~kg} \mathrm{P}^{-1}\right)$ and two levels of weeding (W1 = no weeding and W2 = hand weeding once) were arranged as sub-plots in split-plot design with three replications. The results indicated a highly significant positive response of mean field pea seed yield, total biomass and number of pods per plant to tillage frequency, phosphorus fertilizer and weeding treatments. Plowing twice, three and four times including the last pass for seed covering resulted in mean seed yield advantages of 38, 55 and 43\%, respectively, compared to the control. Application of phosphorus fertilizer at the rates of 10, 20 and $30 \mathrm{~kg} \mathrm{P} \mathrm{ha}^{-1}$ increased mean seed yields by 30,53 and 50\%, respectively, compared to the control. Weeding once by hand increased mean seed yield by 16\% compared to the unweeded check. Tillage frequency by $\mathrm{P}$ fertilizer and weed control interaction significantly affected seed yield. The highest mean seed yield of two years for the tillage, P fertilizer and weed control interaction was obtained from three plowings, 20 $\mathrm{kg} \mathrm{P} \mathrm{ha}{ }^{-1}$ and weeding once by hand. The yield increment was higher by $232 \%$ compared to the control, namely planting with the first pass of ox-drawn implement, with no $\mathrm{P}$ application and unweeded condition. Seed yield was highly significantly and positively correlated with total biomass $\left(\mathrm{r}=0.93^{* *}\right)$, pods per plant $\left(\mathrm{r}=0.54^{* *}\right)$, plant height $(\mathrm{r}$ $\left.=0.54^{* *}\right)$, seeds per pod $\left(\mathrm{r}=0.41^{* *}\right)$ and thousand seeds weight $\left(\mathrm{r}=0.37^{* *}\right)$. The results of economic analysis indicated that the treatment with three times tillage, application of $20 \mathrm{~kg} \mathrm{P} \mathrm{ha}^{-1}$ and weeding once by hand is the best option with a marginal rate of return of $423 \%$, which is economically the most feasible alternative.
\end{abstract}

Keywords: Field Pea; Nitisols; Phosphorus; Tillage Frequency; Weed Control

\section{Introduction}

Although field pea is one of the important grain legumes in Ethiopia, its productivity is low due to several factors, among which the major ones are poor seedbed preparation, untimely sowing, poor soil fertility, inadequate weed control and the lack of improved varieties (Alem et al., 1990; Asfaw et al., 1994). The primary objectives of soil tillage are to provide suitable seedbed and adequate weed control (Rao, 2000). Traditionally, farmers use the local plow for tillage operations to prepare seedbeds. However, the preparation of appropriate weed free seedbeds for crop establishment and production is a problem to field pea and faba bean productions in Ethiopia. Farmers do not practice preplanting tillage for field pea production compared to most cereals. In most cases, field pea is sown with the first plowing. This leads for uneven germination of seeds, high weed pressure and poor plant stand, which in, the final analysis, results in reduced yields.

Research results showed that plowing frequency and weed control operation significantly increased yield of faba bean (Getachew et al., 2005). Hebblethwaite et al. (1983) reported that deep loosening of the soil profile to a depth of $90 \mathrm{~cm}$ resulted in a considerable increase in yields of faba bean. Increased plowing frequency reduces the occurrence and distribution of weeds (Tolera and Daba, 2004). A review by Amare and Adamu (1994) also indicated that repeated plowings significantly increased yields of field pea. The highest seed yield of field pea with a yield advantage of $62 \%$ over the control was obtained from plowing twice followed by plowing three times with a yield advantage of $37 \%$ (Amare and Adamu, 1994).
Acidic Nitisols are of wide occurrence in the highlands of Ethiopia where the rainfall intensity is high and the land has been under cultivation for many years. These soils have $\mathrm{pH}$ values of less than 5.5 , thereby resulting in low yields. The low yields in such soils could mainly be either due to the deficiency of nutrients, such as $\mathrm{P}, \mathrm{Ca}$ and $\mathrm{Mg}$ (Taye and Höfner, 1993; Getachew and Sommer, 2000), or due to toxicity of Al, Fe and Mn (Sharma et al., 1990). The growth and grain yield of field pea is affected by fertilizer application. Results of fertilizer trials indicated that field pea grain yield significantly increased over the control due to application of $\mathrm{P}$ fertilizer (Getachew et al., 2003). The application of $18 / 20 \mathrm{~kg} \mathrm{~N} / \mathrm{P} \mathrm{ha}{ }^{-1}$ increased field pea grain yield by $103 \%$ compared to the unfertilized plots. Angaw and Asnakew (1994) also reported that the response of field pea to $\mathrm{P}$ fertilizer was very high at many locations.

Traditionally, field pea is cultivated under no weeding conditions. Rezene (1986) reported that the major reason for sub-optimal weeding of field pea is the overlapping of farm activities with other crop enterprises. However, experimental evidence indicated that significant reduction in field pea yield potential occurred because of no weeding during the beginning and post-flowering stages of the crop (Rezene, 1986, 1994). Weed competition is high, especially in fields where the land preparation is poor. The efficiency of fertilizer is also low in such fields. Piecemeal research results of these factors have shown positive effects on growth and yield of field pea. However, previous research findings were generated in research centers, with no consideration of differences in soil fertility and weed flora on farmers' fields. Another reason worth mentioning for conducting the current study is to 
find out whether the interaction of tillage, fertilizer and weed control exists. Furthermore, economic feasibilities was not considered in recommending the combined results of tillage frequency, fertilizer and weed control for field pea production on Nitisols of the central Ethiopian highlands. Thus, the objectives of the study were to determine the: (1) effects of tillage, phosphorus fertilizer and weed control practice and their interactions on yield and yield components of field pea at two locations in West Shewa Zone, central highlands of Ethiopia, and (2) the economic feasibility of the practice for field pea production.

\section{Materials and Methods}

\subsection{Experimental Site}

The trial sites were located on the farmers' fields of Welmera and Chelia Districts of West Shewa, central highlands of Ethiopia, at an altitude of about 2400 and $2700 \mathrm{~m}$ above sea level, respectively. In Welmera, the long-term average annual precipitation is $1100 \mathrm{~mm}$, about
$85 \%$ of which is received from June to September and average minimum and maximum air temperatures are 6.1 and $21.9^{\circ} \mathrm{C}$, respectively. The farming system of the trial sites is crop-livestock mixed farming system. The major soil type of both trial sites is Nitisols.

\subsection{Soil Sampling and Analysis}

Selected soil chemical properties of the experimental fields, which are shown in Table 1, were determined for samples taken during planting in the soil and plant analysis laboratory of the Holetta Agricultural Research Center. Soil reaction $(\mathrm{pH})$ was measured in $\mathrm{H}_{2} \mathrm{O}$ with a liquid to solid ratio of 1:1. Likewise, total nitrogen was determined using the Kjeldahl method (Bremner and Mulvaney, 1982). Available phosphorus was determined using the Bray-II method (Bray and Kurtz, 1945). Exchangeable cations and cation exchange capacity (CEC) were analyzed using the ammonium acetate method (Black, 1965).

Table 1. Some soil chemical characteristics $(0-20 \mathrm{~cm}$ depth) of the experimental sites at Welmera and Chelia.

\begin{tabular}{lrcr}
\hline Parameter & Welmera & Chelia & Mean \\
\hline $\mathrm{pH}\left(1: 1 \mathrm{H}_{2} \mathrm{O}\right)$ & 4.73 & 4.65 & 4.69 \\
Total nitrogen $(\%)$ & 0.19 & 0.31 & 0.25 \\
Available P $\left(\mathrm{mg} \mathrm{kg}^{-1}\right)$ & 8.45 & 6.72 & 7.59 \\
Exchangeable Na $\left(\mathrm{cmol}(+) \mathrm{kg}^{-1}\right)$ & 0.03 & 0.10 & 0.07 \\
Exchangeable K $\left(\mathrm{cmol}(+) \mathrm{kg}^{-1}\right)$ & 1.71 & 1.25 & 1.48 \\
Exchangeable Ca $\left(\mathrm{cmol}(+) \mathrm{kg}^{-1}\right)$ & 8.05 & 2.47 & 5.26 \\
Exchangeable $\mathrm{Mg}\left(\mathrm{cmol}(+) \mathrm{kg}^{-1}\right)$ & 1.92 & 2.17 & 2.05 \\
$\mathrm{CEC}\left(\mathrm{cmol}(+) \mathrm{kg}^{-1}\right)$ & 21.74 & 21.48 & 21.62 \\
\hline
\end{tabular}

\subsection{Experimental Design and Procedure}

The experiment was conducted to determine the effects of tillage frequency, $\mathrm{P}$ fertilizer and weed control and their interactions on field pea for two years (2003 and 2004 main cropping seasons) at two locations. The experimental design was split plot with tillage treatments as main plots, and phosphorus fertilizer and weed control as sub-plots with three replications. The treatments included four levels of tillage frequency (four times tillage = April, May, early June and at planting; three times tillage $=$ May, early June and at planting; twice tillage $=$ May and at planting and one time tillage = at planting) and factorial combinations of four levels of $\mathrm{P}$ fertilizer $(0$, 10,20 and $\left.30 \mathrm{~kg} \mathrm{P} \mathrm{ha}^{-1}\right)$ and two levels of weeding $\left(\mathrm{W}_{1}=\right.$ no weeding, and $\mathrm{W}_{2}=$ hand weeding once). Experimental fields were plowed by ox-drawn local plow. Phosphorus fertilizer was applied along with seeds as a single application in the form of triple super-phosphate. Experimental plots received blanket application of $20 \mathrm{~kg}$ $\mathrm{N} \mathrm{ha}^{-1}$ as a starter dressing at planting in the form of urea.

An improved field pea cultivar (Tegegnech) was planted at the seed rate of $150 \mathrm{~kg} \mathrm{ha}^{-1}$. Sowing took place as per recommendation from 20 to 25 June at Welmera and the first week of July at Chelia each season. The crop rotation followed was field pea after food barley in the first year and after wheat in the second year at Welmera, and field pea after food barley both in the first and second years at Chelia. Plots receiving weed control treatment were weeded once by hand at the proper growth stage of plants.

\subsection{Data Collection}

Agronomic parameters collected included plant stand counts $\mathrm{m}^{-2}$ at complete emergence and harvest, plant height (average of ten plants), weed oven dry weight at weeding and harvesting of plants, number of pods per plant and seeds per pod (average of ten plants), total aboveground biomass, seed yield and thousand seed weight of field pea. To estimate total biomass and seed yield of field pea, sample size of $12 \mathrm{~m}^{2}$ was harvested from each plot in November at Welmera and in December at Chelia. After threshing, the harvested materials, seeds were cleaned, weighed and adjusted to $10 \%$ moisture level. Total biomass and seed yield recorded on plot basis were converted to $\mathrm{kg} \mathrm{ha}^{-1}$ for statistical analysis.

\subsection{Statistical Analysis}

The crop data were subjected to analysis of variance using the General Linear Model Procedure of SAS statistical package version 8.2 (SAS Institute, 2001). Data were combined over two years and two locations as the variances were homogenous. The total variability for each trait was quantified using pooled analysis of variance over years and locations. The least significant difference (LSD) test at 5\% level of significance was used to compare the means. Pearson's correlation coefficients were also 
performed using the standard procedures from SAS program.

\subsection{Economic Analysis}

Data on land preparation and weeding (pair of oxen and labor person-days), fertilizer and seed prices were collected to investigate the economic feasibility of the treatments. Partial budget, dominance and marginal analyses were conducted. The average yield from the onfarm experimental plots was adjusted downward by $10 \%$ to reflect the difference between the experimental yield and the yield farmers could expect from the same treatment. This is because experimental yields, even from on-farm experiments under representative conditions, are often higher than the yields that farmers could expect using the same treatments. The two years (2007and 2008) average price (ETB $5.55 \mathrm{~kg}^{-1}$ ) of field pea was used to convert the adjusted yields into gross field benefits. The costs of tillage for a pair of oxen (ETB 50.00 per day), phosphate fertilizer (ETB $7.48 \mathrm{~kg}^{-1}$ ) and weeding (ETB 10.00 per person-day) were also taken from the farmers' own practices in the study areas. For a treatment to be considered as a worthwhile option to farmers, the marginal rate of return (MRR) needed to be at least between 50 and 100\% (CIMMYT, 1988). Researchers in other parts of the country suggested a MRR of $100 \%$ as realistic (Amanuel et al., 1991). Thus, to make recommendations to farmers based on analysis, the minimum acceptable rate of return by the farmers was taken to be $100 \%$.

\section{Results and Discussion}

\subsection{Yield and Yield Components}

On average, over the two experimental years, the data from this study revealed that the frequency of tillage, $\mathrm{P}$ fertilization and weed control treatments had significant effects on yield and yield components of field pea. Analysis of variance indicated that mean field pea seed yield, total plant biomass, number of pods per plant and seeds per pod highly significantly $(P<0.001)$ responded to the frequency of tillage, $\mathrm{P}$ fertilization and weed control (Table 2). Experimental locations and cropping seasons also significantly affected field pea growth, yield and weed biomass both at weeding and harvesting.

The mean field pea seed yield record was higher at Chelia (1799 $\left.\mathrm{kg} \mathrm{ha}{ }^{-1}\right)$ than at Welmera (1387 kg ha-1). While there was a significant difference between each of the tillage frequency, the highest mean seed yield of two years was recorded from plots plowed three times (Table 3). Plowing twice, three and four times, including the last pass for seed covering, increased mean seed yield of field pea by 38, 55 and $43 \%$, respectively, compared to the control. Likewise, experimental findings at Holetta and Shamboo showed that repeated plowings before planting significantly increased seed yields of field pea and faba bean (Amare and Adamu, 1994; Tolera and Daba, 2004). Bellido et al. (2003) also reported that in three rainy years, pre-planting conventional tillage was found to be more productive than no tillage for faba bean production.

Harvest index was significantly different among $\mathrm{P}$ levels $(P<0.001)$ and between weed control treatments $(P<$ 0.01 ) but not among tillage frequencies (Table 2).
Similarly, thousand seeds weight, plant height and plant stand count at harvesting significantly $(P<0.05$ to $P<$ 0.001)) differed among tillage frequencies, $P$ fertilization and between weed control treatments. Weed over dry weight at weeding was highly significantly $(P<0.001)$ affected by tillage frequency and significantly $(P<0.05)$ by $\mathrm{P}$ fertilization but not by weed control. Weed oven dry weight at harvesting also highly significantly $(P<0.001)$ responded to tillage frequency, $\mathrm{P}$ fertilization and weed control. Furthermore, total above ground biomass, number of pods per plant and plant height of field pea were highly significantly affected $(P<0.001)$ by the main effects of tillage, $P$ fertilizer rate and weeding (Table 2). Accordingly, the highest mean total field pea biomass, number of pods per plant and plant height were recorded from three times tillage compared to other tillage frequencies (Tables 3 and 4). Similarly, weeding once and $\mathrm{P}$ fertilization at the rate of $20 \mathrm{~kg} \mathrm{P} \mathrm{ha}{ }^{-1}$ gave the highest total above ground biomass yield and number of pods per plant among the treatments of the respective factors.

Yield and major yield components of field pea positively and significantly $(P<0.001)$ responded to $\mathrm{P}$ fertilizer. The application of $\mathrm{P}$ fertilizer at the rates of 10 , 20 and $30 \mathrm{~kg} \mathrm{P} \mathrm{ha}{ }^{-1}$ resulted in seed yield advantages of 30,53 and $50 \%$, respectively, compared to no P fertilizer treatment (Table 3). The results of the study indicated that the highest mean seed yield of field pea was obtained from the application of $20 \mathrm{~kg} \mathrm{P} \mathrm{ha-1}$ although it did not differ significantly from the yield with $30 \mathrm{~kg} \mathrm{P} \mathrm{ha-1}$. Experimental findings on Nitisols and Alfisols of different locations of the country also showed that the application of phosphate fertilizer increased seed yields of field pea (Angaw and Asnakew, 1994; Getachew et al., 2003; Amare et al., 2005). The optimum dose of $\mathrm{P}$ for attaining an economic yield of field pea was found to be 20 $\mathrm{kg} \mathrm{ha}{ }^{-1}$. Total biomass, harvest index, number of pods per plant and seeds per pod, plant stand count at harvesting, and weed biomass at weeding and at harvesting increased as $\mathrm{P}$ level increased up to $20 \mathrm{~kg} \mathrm{P} \mathrm{ha}{ }^{-1}$ but decreased at 30 kg P ha ${ }^{-1}$ (Tables 3 and 4). In contrast, thousand seeds weight and plant height consistently increased as $\mathrm{P}$ rate increased.

The results of soil analysis were found to be suboptimal for the production of field pea (Table 1). The soil $\mathrm{pH}$ and available $\mathrm{P}$ were below the optimum range. This had a direct relationship with the response of yield to applied phosphorus. In most cases, soils with $\mathrm{pH}$ less than 5.5 are deficient in available $\mathrm{P}, \mathrm{Ca}$ and/or $\mathrm{Mg}$ (Cooke, 1986; Marschner, 1995; Getachew and Sommer, 2000). In such soils, the proportion of P fertilizer that could immediately be available to a crop becomes inadequate and residues of the fertilizer may be released very slowly (Sikora et al., 1991). Legume species differ widely in their ability to grow in soils of low $\mathrm{P}$ status. Mahler et al. (1988) reported that, in terms of nutrient availability, field pea, lentil, chickpea and faba bean grow best in soils with $\mathrm{pH}$ values between 5.7 and 7.2 and require between 13 and $35 \mathrm{~kg} \mathrm{P} \mathrm{ha}^{-1}$ for adequate yields, which agrees with the findings of this study. When pulse crops are grown on soils with $\mathrm{pH}$ values of less than 5.6, they give low yields (Mahler et al., 1988). 
Table 2. Significance of mean squares for yield, yield components and agronomic traits of field pea analyzed for the effects of tillage frequency, $\mathrm{P}$ fertilizer rate and weeding at two locations for two years.

\begin{tabular}{|c|c|c|c|c|c|c|c|c|c|c|c|}
\hline \multirow{2}{*}{$\begin{array}{l}\text { Source } \\
\text { variation }\end{array}$} & \multirow[t]{2}{*}{ df } & \multicolumn{10}{|c|}{ Yield, yield components and agronomic traits of field pea and weed biomass ${ }^{a}$} \\
\hline & & SY & BY & $\mathrm{HI}$ & TSW & SPP & PPP & $\mathrm{PH}$ & SC & $\mathrm{WDM}_{1}$ & $\mathrm{WDM}_{2}$ \\
\hline Year $(Y)$ & 1 & $* * *$ & $* * *$ & ** & ** & $*$ & ns & ** & ** & $* *$ & $* * *$ \\
\hline Location (L) & 1 & $*$ & $* * *$ & $* *$ & $* *$ & ns & $* *$ & $* *$ & $* *$ & $* * *$ & $* * *$ \\
\hline $\mathrm{Y} \times \mathrm{L}$ & 1 & $* * *$ & $* * *$ & $* * *$ & $* * *$ & ns & ns & ns & $*$ & $* * *$ & $* * *$ \\
\hline Tillage $(\mathrm{T})$ & 3 & $* * *$ & $* * *$ & ns & $*$ & $* *$ & $* * *$ & $* * *$ & $* *$ & $* * *$ & $* * *$ \\
\hline $\mathrm{Y} \times \mathrm{T}$ & 3 & $*$ & $*$ & ns & ns & ns & ns & $* *$ & ns & $*$ & $* * *$ \\
\hline $\mathrm{L} \times \mathrm{T}$ & 3 & $*$ & $* * *$ & ns & ns & ns & ns & ns & ns & $* * *$ & $* * *$ \\
\hline $\mathrm{Y} \times \mathrm{L} \times \mathrm{T}$ & 3 & ns & $* * *$ & ns & ns & ns & ns & ns & ns & $* * *$ & $* * *$ \\
\hline Phosphorus (P) & 3 & $* * *$ & $* * *$ & $* * *$ & $* * *$ & $* * *$ & $* * *$ & $* * *$ & $* *$ & $*$ & $* * *$ \\
\hline $\mathrm{Y} \times \mathrm{P}$ & 3 & $*$ & $*$ & ns & ns & ns & ns & ns & $*$ & $*$ & ns \\
\hline $\mathrm{L} \times \mathrm{P}$ & 3 & ns & $*$ & $*$ & ns & ns & ns & ns & ns & ns & ns \\
\hline $\mathrm{T} \times \mathrm{P}$ & 9 & $* * *$ & $* *$ & ns & ns & $*$ & ns & * & $*$ & $* * *$ & $* * *$ \\
\hline $\mathrm{Y} \times \mathrm{L} \times \mathrm{P}$ & 3 & $*$ & ns & ns & ns & ns & ns & ns & ns & ns & ns \\
\hline $\mathrm{Y} \times \mathrm{T} \times \mathrm{P}$ & 9 & ns & $* *$ & $* * *$ & ns & $*$ & ns & ns & ns & ns & $* * *$ \\
\hline $\mathrm{L} \times \mathrm{T} \times \mathrm{P}$ & 9 & ns & ns & ns & ns & ns & ns & ns & ns & $\mathrm{ns}$ & $* * *$ \\
\hline $\mathrm{Y} \times \mathrm{L} \times \mathrm{T} \times \mathrm{P}$ & 12 & ns & ns & ns & ns & ns & ns & ns & ns & ns & $* * *$ \\
\hline Weeding (W) & 1 & $* * *$ & $* * *$ & $* *$ & $* *$ & $* * *$ & $* * *$ & $* * *$ & $* * *$ & ns & $* * *$ \\
\hline $\mathrm{Y} \times \mathrm{W}$ & 1 & $* * *$ & ns & $* *$ & ns & ns & ns & ns & ns & ns & $* * *$ \\
\hline $\mathrm{L} \times \mathrm{W}$ & 1 & $* * *$ & $* * *$ & ns & ns & ns & ns & $*$ & ns & ns & $* * *$ \\
\hline $\mathrm{T} \times \mathrm{W}$ & 3 & $* *$ & $*$ & $*$ & $\mathrm{~ns}$ & ns & ns & $*$ & $*$ & ns & $* * *$ \\
\hline $\mathrm{Y} \times \mathrm{L} \times \mathrm{W}$ & 1 & $* *$ & $* *$ & ns & ns & ns & ns & $*$ & ns & ns & $* * *$ \\
\hline $\mathrm{Y} \times \mathrm{T} \times \mathrm{W}$ & 3 & ns & ns & $*$ & ns & ns & $\mathrm{ns}$ & ns & ns & $* * *$ & $\mathrm{~ns}$ \\
\hline $\mathrm{L} \times \mathrm{T} \times \mathrm{W}$ & 3 & ns & ns & ns & ns & ns & ns & ns & ns & $* *$ & $* * *$ \\
\hline $\mathrm{Y} \times \mathrm{L} \times \mathrm{W}$ & 3 & ns & $\mathrm{ns}$ & ns & $\mathrm{ns}$ & ns & $\mathrm{ns}$ & ns & ns & $*$ & $* * *$ \\
\hline $\mathrm{P} \times \mathrm{W}$ & 3 & ns & ns & ns & ns & ns & $* * *$ & ns & $* *$ & $* *$ & $* * *$ \\
\hline $\mathrm{Y} \times \mathrm{P} \times \mathrm{W}$ & 3 & ns & $* *$ & $* * *$ & $* *$ & ns & ns & ns & ns & ns & $* * *$ \\
\hline $\mathrm{L} \times \mathrm{P} \times \mathrm{W}$ & 3 & ns & & ns & ns & ns & ns & ns & ns & ns & $* * *$ \\
\hline $\mathrm{T} \times \mathrm{P} \times \mathrm{W}$ & 9 & $*$ & $* *$ & $*$ & ns & $*$ & ns & $*$ & $*$ & $*$ & $* * *$ \\
\hline $\mathrm{Y} \times \mathrm{L} \times \mathrm{P} \times \mathrm{W}$ & 3 & ns & ns & ns & ns & ns & ns & ns & ns & ns & $* * *$ \\
\hline $\mathrm{Y} \times \mathrm{T} \times \mathrm{P} \times \mathrm{W}$ & 9 & $* *$ & $* *$ & $*$ & ns & ns & ns & ns & $* *$ & ns & $*$ \\
\hline $\mathrm{Y} \times \mathrm{L} \times \mathrm{T} \times \mathrm{P} \times \mathrm{W}$ & 21 & ns & ns & $\mathrm{ns}$ & ns & ns & ns & ns & ns & ns & $* * *$ \\
\hline $\mathrm{CV}(\%)$ & & 12.2 & 12.4 & 11.4 & 4.8 & 13.8 & 15.6 & 7.2 & 12.5 & 24.7 & 14.5 \\
\hline
\end{tabular}

Weed control had a significant $(P<0.001)$ effect on seed yield, total biomass, number of pods per plant and seeds per pod, plant height, plant stand count and weed oven dry matter weight at harvesting and at $P<0.01$ on harvest index and thousand seeds weight (Table 2). Nevertheless, weed oven dry matter weight at weeding was not significantly affected $(P>0.05)$ by weeding. Weeding once by hand at the proper growth stage of the plant resulted in mean seed yield advantage of 16\% compared to the unweeded control treatment (Table 3). Similarly, a review by Rezene (1994) indicated that weed control operation at the proper growth stages of plants significantly increased seed yield and major yield components of field pea. Results of studies have shown that full-season weed competition caused yield reduction up to $15.3 \%$ in field pea (Rezene, 1986). The presence of weeds during the first 4, 7 and 10 weeks after sowing accounted for respective yield reduction of $0,43.3$ and $66.9 \%$ in field pea (Rezene, 1986). Knott and Halila (1988) also reported substantial yield reduction in food legumes due to weed competition. As depicted in the economic analysis, pre-planting tillage decreased to a great extent the amount of labor required to control weeds. The intensity and distribution of weeds decreased consistently as the frequency of tillage increased.

The critical period of weed competition in cool-season food legumes varies from 3 to 8 weeks after crop emergence. The extent to which the yield is reduced by weeds depends not only on the weed species and density, but also on the period for which the crop is exposed to weeds. The results of the study revealed that the weight of weed biomass at harvesting decreased to a great extent by $35 \%$ due to weeding compared to the weed biomass recorded in the unweeded conditions (Table 4). Weed biomass both at weeding and harvesting were higher at Chelia than at Welmera, in which field pea was grown after barley at Chelia, and after barley and wheat at Welmera. The plant groups most affected by tillage were the broadleaved weeds. The intensity of weed infestation was dependent not only on the soil tillage treatment but also on the herbicide level used on the preceding cereal crop (Rao, 2000). The higher the herbicide level, the lower the total dry matter production measured. 

Table 3. Response of mean yield and yield components of field pea to the main effects of the factors.

\begin{tabular}{|c|c|c|c|c|c|c|}
\hline \multirow[b]{2}{*}{ Factor } & \multicolumn{6}{|c|}{ Mean field pea yield and yield components ${ }^{a}$} \\
\hline & SY $\left(\mathrm{kg} \mathrm{ha}^{-1}\right)^{\mathrm{b}}$ & BY $\left(\mathrm{kg} \mathrm{ha}^{-1}\right)$ & HI $(\%)$ & TSW (g) & PPP (No.) & SPP (No.) \\
\hline \multicolumn{7}{|l|}{ Location: } \\
\hline Welmera & $1387 b$ & $3840 \mathrm{~b}$ & $36.0 \mathrm{a}$ & $173 b$ & $6.5 b$ & 4.3 \\
\hline Chelia & $1799 \mathrm{a}$ & $5436 a$ & $34.0 \mathrm{~b}$ & $203 a$ & $6.8 \mathrm{a}$ & 4.5 \\
\hline LSD (0.05) & 39.16 & 114.22 & 0.77 & 1.88 & 0.22 & Ns \\
\hline \multicolumn{7}{|l|}{ Tillage frequency: } \\
\hline Once & $1187 d$ & $3449 c$ & 34 & $192 \mathrm{a}$ & $5.6 \mathrm{~b}$ & $4.1 \mathrm{~b}$ \\
\hline Twice & $1642 c$ & $4872 b$ & 34 & $187 \mathrm{bc}$ & $6.9 \mathrm{a}$ & $4.5 \mathrm{a}$ \\
\hline Three times & $1841 \mathrm{a}$ & $5259 \mathrm{a}$ & 35 & $188 b$ & $7.1 \mathrm{a}$ & $4.5 \mathrm{a}$ \\
\hline Four times & $1702 b$ & $4974 b$ & 35 & $185 \mathrm{c}$ & $6.9 \mathrm{a}$ & $4.4 \mathrm{a}$ \\
\hline LSD (0.05) & 55.38 & 161.53 & Ns & 2.66 & 0.30 & 0.18 \\
\hline \multicolumn{7}{|c|}{ Phosphorus fertilization $\left(\mathrm{kg} \mathrm{ha}^{-1}\right)$ : } \\
\hline 0 & $1195 c$ & $3575 c$ & $33 c$ & $185 c$ & $5.4 \mathrm{c}$ & $4.1 \mathrm{~b}$ \\
\hline 10 & $1551 b$ & $4594 b$ & $34 \mathrm{bc}$ & $187 \mathrm{bc}$ & $6.7 \mathrm{~b}$ & $4.5 \mathrm{a}$ \\
\hline 20 & $1830 \mathrm{a}$ & $5236 a$ & $36 \mathrm{a}$ & $189 \mathrm{ab}$ & $7.3 \mathrm{a}$ & $4.6 \mathrm{a}$ \\
\hline 30 & $1796 a$ & $5149 \mathrm{a}$ & $35 \mathrm{ab}$ & $191 \mathrm{a}$ & $7.1 \mathrm{a}$ & $4.5 \mathrm{a}$ \\
\hline LSD (0.05) & 55.38 & 161.53 & 1.10 & 2.66 & 0.30 & 0.18 \\
\hline \multicolumn{7}{|c|}{ Weeding frequency: } \\
\hline Unweeded & $1474 b$ & $4369 \mathrm{~b}$ & $34.0 \mathrm{~b}$ & $190 \mathrm{a}$ & $6.2 \mathrm{~b}$ & $4.2 \mathrm{~b}$ \\
\hline Once weeded & $1712 \mathrm{a}$ & $4908 \mathrm{a}$ & $35.0 \mathrm{a}$ & $186 b$ & $7.1 \mathrm{a}$ & $4.6 \mathrm{a}$ \\
\hline LSD (0.05) & 39.16 & 114.22 & 0.77 & 1.88 & 0.22 & 0.13 \\
\hline
\end{tabular}

${ }^{a}$ Means within a column of the same factor followed by the same letter(s) are not significantly different at $P<0.05$.

${ }^{b} S Y=$ Seed yield; BY = Biomass yield; HI = Harvest index; TSW = Thousand seeds weight; PPP = Pods per plant; SPP = Seeds per pod; $n$ s $=$ Not significant at $P>0.05$.

Table 4. Response of some agronomic traits of field pea and weed biomass to the main effects of the factors.

\begin{tabular}{|c|c|c|c|c|}
\hline Factor $^{\mathrm{d}}$ & Plant height $(\mathrm{cm})$ & Stand count $\mathrm{m}^{-2}$ & $\mathrm{WDM}_{1}\left(\mathrm{~g} \mathrm{~m}^{-2}\right)^{e}$ & $\mathrm{WDM}_{2}\left(\mathrm{~g} \mathrm{~m}^{-2}\right)$ \\
\hline \multicolumn{5}{|l|}{ Location: } \\
\hline Welmera & $107 b$ & $50 \mathrm{~b}$ & $41 b$ & $39 \mathrm{~b}$ \\
\hline Chelia & $111 \mathrm{a}$ & $53 \mathrm{a}$ & $57 \mathrm{a}$ & $61 \mathrm{a}$ \\
\hline LSD (0.05) & 1.41 & 1.29 & 2.56 & 1.68 \\
\hline \multicolumn{5}{|l|}{ Tillage frequency: } \\
\hline Once & $102 \mathrm{c}$ & $47 \mathrm{~b}$ & $82 \mathrm{a}$ & $108 \mathrm{a}$ \\
\hline Twice & $110 \mathrm{~b}$ & $51 \mathrm{a}$ & $48 b$ & $43 b$ \\
\hline Three times & $113 \mathrm{a}$ & $53 a$ & $34 c$ & $23 c$ \\
\hline Four times & $112 \mathrm{ab}$ & $52 \mathrm{a}$ & $32 \mathrm{c}$ & $24 \mathrm{c}$ \\
\hline LSD (0.05) & 2.00 & 1.82 & 3.62 & 2.38 \\
\hline \multicolumn{5}{|c|}{ Phosphorus fertilization $\left(\mathrm{kg} \mathrm{ha}^{-1}\right)$ : } \\
\hline 0 & $99 \mathrm{c}$ & $49 \mathrm{~b}$ & $46 \mathrm{~b}$ & $48 \mathrm{~b}$ \\
\hline 10 & $111 b$ & $52 \mathrm{a}$ & $49 \mathrm{ab}$ & $48 b$ \\
\hline 20 & $113 \mathrm{ab}$ & $53 \mathrm{a}$ & $51 \mathrm{a}$ & $51 \mathrm{a}$ \\
\hline 30 & $114 \mathrm{a}$ & $53 \mathrm{a}$ & $50 \mathrm{a}$ & $51 \mathrm{a}$ \\
\hline LSD (0.05) & 2.00 & 1.82 & 3.62 & 2.38 \\
\hline \multicolumn{5}{|c|}{ Weeding frequency: } \\
\hline Unweeded & $107 b$ & $50 \mathrm{~b}$ & 48 & $60 \mathrm{a}$ \\
\hline Once weeded & $112 \mathrm{a}$ & $53 a$ & 50 & $39 \mathrm{~b}$ \\
\hline LSD (0.05) & 1.41 & 1.29 & ns & 1.68 \\
\hline
\end{tabular}

${ }^{\top}$ Means within a column of the same factor followed by the same letters are not statistically different at $P>0.05$.

${ }^{e} W D M_{1}=W e e d$ dry matter at weeding; $W D M_{2}=W e e d$ dry matter at harvesting; $n s=$ Not significant at $P>0.05$.

The combined analysis of variance over the two cropping seasons showed that there were significant $(P<0.05 ; P<$ 0.01 and $P<0.001)$ year by location $(\mathrm{Y} \times \mathrm{L})$, tillage by $\mathrm{P}$ fertilization $(\mathrm{T} \times \mathrm{P})$, location by weeding $(\mathrm{L} \times \mathrm{W})$, tillage by weeding $(\mathrm{T} \times \mathrm{W})$, tillage by $\mathrm{P}$ fertilization and weeding $(\mathrm{T} \times \mathrm{P} \times \mathrm{W})$, and year by tillage, $\mathrm{P}$ fertilization and weeding $(\mathrm{Y} \times \mathrm{T} \times \mathrm{P} \times \mathrm{W})$ interactions for mean field pea seed yield, total biomass and weed biomass at harvesting (Table 2).
The seed yield of field pea obtained from the control (once tillage and no $\mathrm{P}$ ) treatment was significantly $(P<$ 0.05) lower compared to yields obtained from any of the remaining combinations of tillage frequency and $\mathrm{P}$ fertilizer rates (Table 5). Twice and three times tillage frequency brought about seed yield increments of 1181 and $1229 \mathrm{~kg} \mathrm{ha}^{-1}$ at $20 \mathrm{~kg} \mathrm{P} \mathrm{ha} \mathrm{P}^{-1}$ compared to field pea seed yield obtained from once tillage and no $\mathrm{P}$ application 
Getachew and Hailu

with yield advantages of 149 and $155 \%$, respectively. Similarly, sowing field pea at the second and third tillage frequencies with $20 \mathrm{~kg} \mathrm{P} \mathrm{ha-1}$ and weeded once condition resulted in yield increases of 1419 and $1617 \mathrm{~kg} \mathrm{ha}^{-1}$, respectively, compared to once tillage, no $\mathrm{P}$ treatment and unweeded conditions (Table 6). The yield increments due to these treatments were 203 and $232 \%$, respectively, compared to the control that is planting with the first pass of ox-drawn implement and with no $\mathrm{P}$ application and unweeded condition. In general, the highest mean seed yield (2314 $\mathrm{kg} \mathrm{ha}^{-1}$ ) of the two years was recorded from three times tillage, application of $20 \mathrm{~kg} \mathrm{P} \mathrm{ha}^{-1}$ and weeding once by hand. Likewise, Getachew et al. (2005) reported that the highest faba bean seed yield for the tillage and weed control interaction was obtained from three times tillage and weeding once by hand.

Table 5. Interaction effects of tillage frequency and P fertilization on mean field pea seed yield $\left(\mathrm{kg} \mathrm{ha}^{-1}\right)$.

\begin{tabular}{lcccc}
\hline Tillage & \multicolumn{4}{c}{ Phosphorus fertilization $\left(\mathrm{kg} \mathrm{ha}^{-1}\right)$} \\
\cline { 2 - 5 } frequency & 0 & 10 & 20 & 30 \\
\hline Once & 794 & 1190 & 1376 & 1389 \\
Twice & 1153 & 1533 & 1975 & 1908 \\
Three times & 1449 & 1840 & 2023 & 2052 \\
Four times & 1383 & 1641 & 1947 & 1836 \\
\hline LSD $(0.05)$ & \multicolumn{5}{c}{126.60} \\
\hline
\end{tabular}

Seed yield was significantly positively correlated with total biomass, number of pods per plant, plant height, number of seeds per pod, thousand seeds weight and plant stand count
East African Journal of Sciences Volume 3 (2) 161-169

at harvesting $\left(\mathrm{r}=0.93^{* * *}, 0.54^{* * *}, 0.54^{* *}, 0.41^{* *}, 0.37^{* *}\right.$ and $0.34^{* *}$, respectively) (Table 7 ). Total plant biomass and number of pods per plant were strongly correlated with seed yield, which indicates that high total aboveground biomass and number of pods per plant are essential for high seed yield production.

Table 6. Interaction effects of tillage, $\mathrm{P}$ fertilizer and weeding on mean field pea seed yield $\left(\mathrm{kg} \mathrm{ha}^{-1}\right)$.

\begin{tabular}{lrcc}
\hline Tillage & $\mathrm{P}\left(\mathrm{kg} \mathrm{ha}^{-1}\right)$ & \multicolumn{2}{c}{ Weeding } \\
\cline { 3 - 4 } Frequency & & Unweeded & Weeded once \\
\hline Once & 0 & 1141 & 892 \\
Once & 10 & 1288 & 1239 \\
Once & 20 & 1267 & 1465 \\
Once & 30 & 1122 & 1511 \\
Twice & 0 & 1347 & 1184 \\
Twice & 10 & 1834 & 2116 \\
Twice & 20 & 1808 & 2007 \\
Twice & 30 & 1295 & 1604 \\
Three times & 0 & 1697 & 1983 \\
Three times & 10 & 1732 & 2314 \\
Three times & 20 & 1901 & 2202 \\
Three times & 30 & 1291 & 1476 \\
Four times & 0 & 1589 & 1693 \\
Four times & 10 & 1879 & 2014 \\
Four times & 20 & 1699 & 1972 \\
Four times & 30 & 179.10 & \\
\hline LSD $(0.05)$ & &
\end{tabular}

Table 7. Coefficients of correlation ( $\mathrm{r}$ ) among yield and agronomic parameters of field pea for mean values of two locations and two cropping seasons.

\begin{tabular}{|c|c|c|c|c|c|c|c|}
\hline Character $^{f}$ & SY & BY & $\mathrm{HI}$ & TSW & SPP & PPP & $\mathrm{PH}$ \\
\hline $\mathrm{SC}$ & $0.34^{* *}$ & $0.31^{* *}$ & $-0.05 \mathrm{~ns}$ & $0.26^{*}$ & $0.24^{*}$ & $-0.004 \mathrm{~ns}$ & $-0.02 \mathrm{~ns}$ \\
\hline $\mathrm{PH}$ & $0.54^{* *}$ & $0.53^{* *}$ & $0.02 \mathrm{~ns}$ & $-0.09 \mathrm{~ns}$ & $0.42^{* *}$ & $0.73^{* * *}$ & \\
\hline PPP & $0.54^{* *}$ & $0.52^{* *}$ & $0.05 \mathrm{~ns}$ & $-0.08 \mathrm{~ns}$ & $0.25^{*}$ & & \\
\hline SPP & $0.41^{* *}$ & $0.42^{* *}$ & $-0.05 \mathrm{~ns}$ & $0.03 \mathrm{~ns}$ & & & \\
\hline TSW & $0.37^{* *}$ & $0.45^{* *}$ & $-0.27 * *$ & & & & \\
\hline $\mathrm{HI}$ & $0.06 \mathrm{~ns}$ & $-0.27^{*}$ & & & & & \\
\hline BY & $0.93^{* * *}$ & & & & & & \\
\hline
\end{tabular}

\subsection{Economic Analysis}

Economic analysis was conducted for tillage frequency, $\mathrm{P}$ fertilizer and weed control experiments taking mean seed yields of two years. As farmers attempt to evaluate the economic benefits of shifts in practice, partial budget analysis was done to identify the rewarding treatments. It is one of the concerns of the farmers to find options of field pea management that can provide better economic advantages. The farmers produce field pea without application of inorganic fertilizer, planting with the first pass and without weed control. These practices cannot, however, enable the farmers to produce as high a yield as possible and to earn the highest number of net benefits as possible. To fill this gap, 32 different management options were compared on farmers' fields to select the best options that can bring the greatest economic advantages.

According to net benefit analysis, positive net benefits ranging from 3179.85 to 9832.65 Ethiopian Birr (ETB) were obtained from producing field pea on a hectare of land (Table 8). The option with three times tillage, application of $20 \mathrm{~kg} \mathrm{P} \mathrm{ha-1}$ and weeding once by hand gave the highest net benefit of 9832.65 ETB. Farmers' practice of once tillage, no fertilizer application and no weeding gave the lowest yield and net benefit of 3179.85 ETB ha-1. Out of the total 32 treatments considered for economic analysis, 21 of them were dominated, indicating that the value of the increase in yields due to these treatments is not enough to compensate for the increase for costs. Hence, no farmer would choose treatments that 
incur additional costs. The dominated treatments were, therefore, eliminated from further economic analysis.

In the end, marginal analysis was conducted for the non-dominated eleven treatments, including the control treatment. In order to make recommendations to farmers based on analysis, the minimum acceptable rate of return by the farmers was assumed to be $100 \%$ for this experiment (Amanuel et al., 1991). This implies that the farmers will not be willing to change their traditional practice of once tillage, no inorganic fertilizer and no weeding unless they get a minimum of $100 \%$ rate of return. If the minimum rate of return is below $100 \%$, the change from one treatment to another will not be acceptable.

According to the results of the marginal analysis, the treatment with three times tillage, application of $20 \mathrm{~kg} \mathrm{P}$ $\mathrm{ha}^{-1}$ and weeding once was identified to be the best option with a marginal rate of return of $423 \%$, well above the minimum acceptable rate of return of $100 \%$ (Table 9). From this treatment, a marginal benefit of 804.00 ETB $\mathrm{ha}^{-1}$ was obtained from investing an extra 190.00 ETB ha 1. Seven other treatments have also given a marginal rate of return well above the minimum rate of return $(100 \%)$, but lower than the rate of return obtained from a treatment with a MRR of $423 \%$. Nonetheless, they can be used as options for farmers with different income levels, in as far as they give a better rate of return than the traditional (control) practice. Therefore, the farmers can get the highest rate of return if they follow an improved agronomic practice with three times tillage, application of $20 \mathrm{~kg} \mathrm{P} \mathrm{ha-1}$ and weeding once by hand for the production of field pea.

Table 8 . Net benefit analysis results of field pea production as influenced by tillage, $\mathrm{P}$ fertilizer and weed control pooled over the two (Chelia and Welmera) locations.

\begin{tabular}{|c|c|c|c|c|c|c|c|c|}
\hline \multirow[t]{2}{*}{ Treatmente } & \multirow{2}{*}{$\begin{array}{r}\text { Mean yield } \\
\left(\mathrm{kg} \mathrm{ha}^{-1}\right)\end{array}$} & \multirow{2}{*}{$\begin{array}{r}\text { Adjusted yield- } \\
10 \%\left(\mathrm{~kg} \mathrm{ha}^{-1}\right)\end{array}$} & \multirow{2}{*}{$\begin{array}{r}\text { Gross benefit } \\
\left(\text { ETB ha }^{-1}\right)\end{array}$} & \multicolumn{4}{|c|}{ Costs that vary $\left(\mathrm{ETB} \mathrm{ha}^{-1}\right)$} & \multirow{2}{*}{$\begin{array}{l}\text { Net benefit } \\
\left(\text { ETB ha- }^{-1}\right)\end{array}$} \\
\hline & & & & Tillage & $\mathrm{P}\left(\mathrm{kg} \mathrm{ha}^{-1}\right)$ & Weeding & Total cost & \\
\hline T1P1W1 & 697 & 627 & 3479.85 & 300 & 0 & 0 & 300 & 3179.85 \\
\hline T1P1W2 & 892 & 803 & 4456.65 & 300 & 0 & 370 & 670 & 3786.65 \\
\hline T1P2W1 & 1141 & 1027 & 5699.85 & 300 & 374 & 0 & 674 & 5025.85 \\
\hline T1P2W2 & 1239 & 1115 & 6188.25 & 300 & 374 & 370 & 1044 & 5144.25 \\
\hline T1P3W1 & 1288 & 1159 & 6432.45 & 300 & 748 & 0 & 1048 & 5384.45 \\
\hline T1P3W2 & 1465 & 1318 & 7314.90 & 300 & 748 & 370 & 1418 & 5896.90 \\
\hline T1P4W1 & 1267 & 1140 & 6327.00 & 300 & 1072 & 0 & 1372 & 4955.00 \\
\hline T1P4W2 & 1511 & 1360 & 7542.45 & 300 & 1072 & 370 & 1742 & 5800.45 \\
\hline T2P1W1 & 1122 & 1010 & 5605.50 & 500 & 0 & 0 & 500 & 5105.50 \\
\hline T2P1W2 & 1184 & 1066 & 5916.30 & 500 & 0 & 290 & 790 & 5126.30 \\
\hline T2P2W1 & 1347 & 1212 & 6726.60 & 500 & 374 & 0 & 874 & 5852.60 \\
\hline T2P2W2 & 1720 & 1548 & 8591.40 & 500 & 374 & 290 & 1164 & 7427.40 \\
\hline T2P3W1 & 1834 & 1651 & 9157.50 & 500 & 748 & 0 & 1248 & 7909.50 \\
\hline T2P3W2 & 2116 & 1904 & 10567.20 & 500 & 748 & 290 & 1538 & 9029.20 \\
\hline T2P4W1 & 1808 & 1627 & 9029.85 & 500 & 1072 & 0 & 1572 & 7457.85 \\
\hline T2P4W2 & 2007 & 1806 & 10023.30 & 500 & 1072 & 290 & 1862 & 8161.30 \\
\hline T3P1W1 & 1295 & 1165 & 6465.75 & 700 & 0 & 0 & 700 & 5765.75 \\
\hline T3P1W2 & 1604 & 1444 & 8014.20 & 700 & 0 & 280 & 980 & 7034.20 \\
\hline T3P2W1 & 1697 & 1527 & 8474.85 & 700 & 374 & 0 & 1074 & 7400.85 \\
\hline T3P2W2 & 1983 & 1785 & 9906.75 & 700 & 374 & 280 & 1354 & 8552.75 \\
\hline T3P3W1 & 1732 & 1559 & 8652.45 & 700 & 748 & 0 & 1448 & 7204.45 \\
\hline T3P3W2 & 2314 & 2083 & 11560.65 & 700 & 748 & 280 & 1728 & 9832.65 \\
\hline T3P4W1 & 1901 & 1711 & 9496.05 & 700 & 1072 & 0 & 1772 & 7724.05 \\
\hline T3P4W2 & 2202 & 1982 & 11000.10 & 700 & 1072 & 280 & 2052 & 8948.10 \\
\hline T4P1W1 & 1291 & 1162 & 6449.10 & 900 & 0 & 0 & 900 & 5549.10 \\
\hline T4P1W2 & 1476 & 1328 & 7370.40 & 900 & 0 & 220 & 1120 & 6250.40 \\
\hline T4P2W1 & 1589 & 1430 & 7936.50 & 900 & 374 & 0 & 1274 & 6662.50 \\
\hline T4P2W2 & 1693 & 1524 & 8458.2 & 900 & 374 & 220 & 1494 & 6964.20 \\
\hline T4P3W1 & 1879 & 1691 & 9385.05 & 900 & 748 & 0 & 1648 & 7737.05 \\
\hline T4P3W2 & 2014 & 1813 & 10062.15 & 900 & 748 & 220 & 1868 & 8194.15 \\
\hline T4P4W1 & 1699 & 1529 & 8485.95 & 900 & 1072 & 0 & 1972 & 6513.95 \\
\hline T4P4W2 & 1972 & 1775 & 9851.25 & 900 & 1072 & 220 & 2192 & 7659.25 \\
\hline
\end{tabular}


Table 9. Marginal analysis of field pea response to tillage, $\mathrm{P}$ fertilizer and weed control for the mean of the two locations (Chelia and Welmera).

\begin{tabular}{|c|c|c|c|c|c|c|}
\hline Treatment $\mathrm{f}^{\mathrm{f}}$ & $\begin{array}{l}\text { Adjusted yield } \\
-10 \%\left(\mathrm{~kg} \mathrm{ha}^{-1}\right) \\
\end{array}$ & $\begin{array}{l}\text { Total cost that } \\
\text { vary }\left(\mathrm{ETB} \mathrm{ha}{ }^{-1}\right)\end{array}$ & $\begin{array}{c}\text { Marginal cost } \\
\left(\text { ETB ha }^{-1}\right)\end{array}$ & $\begin{array}{l}\text { Net benefit } \\
(\text { ETB ha-1) }\end{array}$ & $\begin{array}{l}\text { Marginal benefit } \\
(\text { ETB ha-1) }\end{array}$ & $\begin{array}{l}\text { Marginal rate } \\
\text { of return }(\%)\end{array}$ \\
\hline T1P1W1 & 627 & 300 & - & 3180.00 & - & - \\
\hline T2P1W1 & 1001 & 500 & 200 & 5105.00 & 1925.00 & 962 \\
\hline T3P1W1 & 1165 & 700 & 200 & 5766.00 & 661.00 & 330 \\
\hline T2P2W1 & 1212 & 874 & 174 & 5853.00 & 87.00 & 50 \\
\hline T3P1W2 & 1444 & 980 & 106 & 7034.00 & 1181.00 & 1114 \\
\hline T3P2W1 & 1527 & 1074 & 94 & 7400.00 & 366.00 & 389 \\
\hline T2P2W2 & 1548 & 1164 & 90 & 7427.00 & 27.00 & 30 \\
\hline T2P3W1 & 1651 & 1248 & 84 & 7909.00 & 482.00 & 574 \\
\hline T3P2W2 & 1785 & 1354 & 106 & 8553.00 & 644.00 & 607 \\
\hline T2P3W2 & 1904 & 1538 & 184 & 9029.00 & 476.00 & 259 \\
\hline T3P3W2 & 2083 & 1728 & 190 & 9833.00 & 804.00 & 423 \\
\hline
\end{tabular}

\section{Acknowledgements}

The authors gratefully acknowledge the Ethiopian Institute of Agricultural Research (EIAR) for funding this experiment. They are also thankful to Mr. Beyene Ofa, Mr. Chanyalew Mandefro and Miss Asnakech Dubale for their assistance in the execution of the field experiments. Appreciation is also due to the Soil Laboratory of Holetta Agricultural Research Center for analytical services.

\section{References}

Alem, B., Beniwal, S.P.S, Amare G., Asfaw, T., Hailu, B. and Saxena, M.C. 1990. On-farm evaluation of four management factors for faba bean production in the Holetta zone of Shewa. Ethiopian Journal of Agricultural Science 12: 17-28.

Amanuel, G., Asefa, T., Douglas, T.G. and Mwangi, W. 1991. On-farm research to derive fertilizer recommendations for small-scale bread wheat production: Methodological issues and technical results. Research Report No. 14. IAR, Addis Ababa, Ethiopia.

Amare, G. and Adamu, M. 1994. Faba bean and field pea agronomy research. In: Asfaw, T., Geletu, B., Saxena, M.C. and Solh, M.B. (eds.). Cool-season food legumes of Ethiopia. Proceedings of the $1^{\text {st }}$ National Cool-season Food Legumes Review Conference, 16-20 December 1993, Addis Ababa, Ethiopia. ICARDA/IAR. ICARDA, Aleppo, Syria. pp.199-229.

Amare, G., Du Preez, C.C. and Taye, B. 2005. Effect of phosphorus fertilizer on grain yield and yield components of field pea. Ethiopian Journal of Natural Resource 7: 1-21.

Angaw, T. and Asnakew, W. 1994. Fertilizer response trials on highland food legumes. In: Asfaw, T., Geletu, B., Saxena, M.C. and Solh, M.B. (eds.). Coolseason food legumes of Ethiopia. Proceedings of the $1^{\text {st }}$ National Cool-season Food Legumes Review Conference, 16-20 December 1993, Addis Ababa, Ethiopia. ICARDA/IAR. ICARDA, Aleppo, Syria. pp.279-292.

Asfaw, T., Geletu, B. and Alem, B. 1994. Role of coolseason food legumes and their production constraints in Ethiopian agriculture. In: Asfaw, T., Geletu, B., Saxena, M.C. and Solh, M.B. (eds.). Proceedings of the $1^{\text {st }}$ National Cool-season Food Legumes Review Conference, 16-20 December 1993, Addis Ababa, Ethiopia. ICARDA/IAR. ICARDA, Aleppo, Syria. pp.3-16.

Bellido, R.J., Bellido, L., Bellido, F.J. and Castillo, J.E. 2003. Faba bean (Vicia faba L.) response to tillage and soil residual nitrogen in a continuous rotation with wheat (Triticum aestivum L.) under rain-fed Mediterranean conditions. Agronomy Journal 95: 12531261.

Black, C.A. 1965. Determination of exchangeable Ca, Mg, $\mathrm{K}, \mathrm{Na}, \mathrm{Mn}$ and effective cation exchange capacity in soil. In: Black, C.A. (ed.). Methods of soil analysis, Agronomy No. 9, Part, 2, American Society of Agronomy, Madison, Wisconsin.

Bray, R.H. and Kurtz, L.T. 1945. Determination of total, organic and available forms of phosphate in soil. Soil Science 59: 39-45.

Bremner, J.M. and Mulvaney, C.S. 1982. Nitrogen total. $2^{\text {nd }}$ edition. In: Page, A.L. (ed.). Methods of soil analysis, Part 2. Chemical and microbiological properties, American Society of Agronomy, Madison, WI. pp.595-624.

CIMMYT (International Maize and Wheat Improvement Center). 1988. From agronomic data to farmer recommendations: Economics training manual. Completely revised ed. CIMMYT, Mexico, D.F.

Cooke, G.W. 1986. Fertilizing for maximum yield. $3^{\text {rd }}$ edition. Mackays of Khatham Ltd., Kent Publishers, U.K.

Getachew, A. and Sommer, K. 2000. Optimization of the efficiency of phosphate fertilizers in acidic-ferralitic soils of the humid tropics. Ethiopian Journal of Natural Resources 2: 63-77.

Getachew, A., Amare, G. and Chilot, Y. 2003. Response of faba bean and field pea to phosphate fertilizer on farmers' fields on Nitisols of Welmera Wereda, west Shewa. In: Tilahun, A. and Eylachew, Z. (eds.). Proceedings of the $6^{\text {th }}$ ESSS Conference, Feb. 28March 1, 2002. Ethiopian Society of Soil Science, Addis Ababa, Ethiopia. pp.13-24. 
Getachew, A., Amare, G. and Agajie, T. 2005. Effect of tillage frequency and weed control on yield and yield components of faba bean in central highlands of Ethiopia. Ethiopian Journal of Agricultural Sciences 18: 165-172.

Hebblethwaite, P.D., Hawtin, G.C. and Latman, P.J.W. 1983. The husbandry of establishment and maintenance. In: Hebblethwaite, P.D. (ed.). Faba bean (Vicia faba L.): A basis for Improvement. Cambridge University Press, UK. pp.271-312.

Knott, C.M. and Halila, H.M. 1988. Weeds in food legumes: Problems, effect and control. In: Summerfield, R.J. (ed.). World Crops: Cool Season Food Legumes. Kluwer Academic Publisher, Dordrecht, the Netherlands. pp.535-548.

Mahler, R.L., Saxena, M.C. and Aeschlimann, J. 1988. Soil fertility requirements of pea, lentil, chickpea and faba bean. In: Summerfield, R.J. (ed.). World crops: Cool season food legumes. Proceedings of the international food legumes research conference on pea, lentil, faba bean and chickpea. Washington, USA. pp.279-289.

Marschner, H. 1995. Mineral nutrition of bigher plants. Academic Press, Harcour Brace Jovanovich Publishers, London.

Rao, V.S. 2000. Principles of Weed Science. 2 ${ }^{\text {nd }}$ edition. Science Publishers, INC., USA.

Rezene, F. 1986. A review of weed science research activities in pulses in Ethiopia. In: Tsedeke, A. (ed.). Proceedings of the $1^{\text {st }}$ Crop Protection Symposium, 4-7 Feb. 1985, IAR, Addis Ababa, Ethiopia. pp.403420 .
Rezene, F. 1994. Weed research in cool season food legumes. In: Asfaw, T., Geletu, B., Saxena, M.C. and Solh, M.B. (eds.). Cool-season food legumes of Ethiopia. Proceedings of the $1^{\text {st }}$ National Cool-season Food Legumes Review Conference, 16-20 December 1993, Addis Ababa, Ethiopia. ICARDA/IAR. ICARDA: Aleppo, Syria. pp.252-275.

SAS (Statistical Analysis Software) Institute. 2001. SAS/STAT user's guide, version 8.2, SAS Inst., Cary, $\mathrm{NC}$.

Sharma, P.K., Verma, T.S. and Gupta, J.P. 1990. Ameliorating effects of phosphorus, lime and animal manure on wheat yield and root cation exchange capacity in degraded Alfisols of North-West Himalayas. Fertilizer Research 23: 7-13.

Sikora, F.J., Copeland, J.P., Mullins, G.L. and Bartos, J.M. 1991. Phosphorus dissolution kinetics and bioavailability of water insoluble fractions from monoammonium phosphate fertilizers. Soil Science Society of America Journal 53: 362-368.

Taye, B. and Höfner, W. 1993. Effects of different Pfertilizers on yield of barley and rapeseed on reddish brown soils of the Ethiopian highlands. Fertilizer Research 34: 243-250.

Tolera, A. and Daba, F. 2004. Effect of plowing frequency, seed rate and weeding frequency on agronomic parameters of faba bean on farmers' fields at Shamboo, Ethiopia. In: Asfaw, Z., Getachew, B., Belay, S., Bulcha, W. and Nigussie, A. (eds.). Proceedings of the $11^{\text {th }}$ CSSE Conference, 26-27 April 2004, Addis Ababa, Ethiopia. pp.183-190. 